\title{
How the Body of Lazarus helps to solve a Pauline Problem
}

\author{
Jennifer R. Strawbridge \\ Mansfield College, Mansfield Road, Oxford, OX1 3TF, UK \\ jennifer.strawbridge@theology.ox.ac.uk
}

\begin{abstract}
While the locus classicus for early Christian arguments concerning resurrection of the flesh is Paul's first Corinthian letter, the statement in 15.50 that "flesh and blood cannot inherit the kingdom of God" complicates early Christian understandings of resurrection and its form. Such explicit denial of fleshly inheritance and resurrection within Paul's writings leads to widely conflicting interpretations of this Corinthian passage. Consequently, early Christian writers such as Irenaeus, Tertullian, and Augustine engaged other New Testament texts such as John 11 in order to subvert the claim of 1 Cor 15.50 and develop their argument for fleshly resurrection.
\end{abstract}

\section{Key Words}

Paul, Resurrection, Lazarus, Gospel of John, 1 Corinthians, History of Reception

The words of the apostle Paul, dubbed the 'Apostle of the resurrection' by one Valentinian writer, ${ }^{1}$ stand at the centre of one of the most heated debates in the second and third centuries. For Irenaeus, Paul's words in 1 Corinthians about resurrection and the flesh are 'adduced by all the heretics in support of their folly, with an attempt to annoy us, ${ }^{2}$ and for Tertullian, excerpts from this letter are what his 'opponents place

\footnotetext{
${ }^{1}$ Clement of Alexandria, Exc. 23.2-3 (SC 23).

${ }^{2}$ Irenaeus, Haer. 5.9.1 (SC 153).
} 
in the front of the battle. ${ }^{3}$ Even Origen is clear in his arguments against Celsus that discussions about the resurrection are 'of a profounder and more mystical nature' than any other. ${ }^{4}$

The locus classicus for early Christian arguments concerning the resurrection of the body is the fifteenth chapter of Paul's first Corinthian letter. Here, Paul announces a resurrection of the Christian dead at the end of time and explores the nature of the resurrected body, offering what many argue to be the most detailed treatment of general resurrection found in the NT. ${ }^{5}$ Within this fifteenth chapter Paul addresses a specific problem in the Corinthian community, namely that some within the community claim 'there is no resurrection of the dead' (15.12). Nevertheless, this part of the letter is not addressed to dissenters, but to the whole community as Paul attempts to reconcile the Corinthians with one another. The theme of resurrection, both of Christ and of all the dead, and the theme of Christ's defeat of the opposing powers are both emphasized with the result that ultimately 'God may be all in all' (15.28). ${ }^{6}$ Within this context, Paul tries to explain the continuity and discontinuity

\footnotetext{
${ }^{3}$ Tertullian, Res. 48.1 (CCL 2).

${ }^{4}$ Origen, Cels. 5.19 (SC 227; Chadwick).

${ }^{5}$ J. Kovacs, ed., 1 Corinthians: Interpreted by Early Christian Commentators (ECCS; Grand Rapids, Mich.: Eerdmans, 2005) 242. See also J. Kovacs, '1 Corinthians', The Oxford Handbook of the Reception History of the Bible (ed. M. Lieb, E. Mason, and J. Roberts; Oxford; Oxford University Press, 2011) 136-48, at 146.

${ }^{6}$ G. D. Fee, The First Epistle to the Corinthians (NICNT; Grand Rapids, Mich.: Eerdmans, 1987) 741.
} 
between the present body and the resurrection body, offering a 'paradoxical description of the resurrection body as a "spiritual body" (15.44). ${ }^{7}$

Beginning with the phrase in 15.50 that 'flesh and blood cannot inherit the kingdom of God,' this text and the images within it figure prominently in early Christian debates about Christology and what happens to the body after death. In fact, excerpts from 1 Corinthians 15 and especially $15.50-58$ are favoured by early Christian writers, ranking sixth in a survey of the use of all Pauline texts in anteNicene Christian writings. ${ }^{8}$ In particular, early Christians focus on the dichotomous images and phrases within this passage and the language used by Paul to describe resurrection. Thus, they adopt phrases such as perishable and imperishable (15.5354), mortal and immortal (15.53-54), and flesh and blood and the kingdom of God (15.50), and use these phrases most frequently within arguments about resurrection and its form. ${ }^{9}$

\footnotetext{
${ }^{7}$ Kovacs, 1 Corinthians, 243.

${ }^{8}$ Other frequently used excerpts from the letters attributed to Paul by early Christians include: 1 Cor 2.6-16, Col 1.15-20, Eph 6.10-17, and Phil 2.5-11. See J. R. Strawbridge, The Pauline Effect: The Use of the Pauline Epistles by Early Christian Writers (SBR 5; Berlin: De Gruyter, 2015) 11 n. 38.

${ }^{9}$ Early Christian writers do use other Pauline texts about resurrection but not as frequently as 1 Cor $15.50-58$, which occurs more than 350 times in ante-Nicene writings. For comparison: 1 Thess 5.1-10 occurs 70 times; 1 Thess 4.13-18: 131 times; Col 2.9-15: just over 150 times; Col 3.1-4: more than 90 times; Rom 6.4-11: approximately 200 times; and 2 Cor 5.1-5: 110 times. See Strawbridge, Pauline
} Effect, 99 n. 14. 
Nevertheless, Paul's words are problematic and create a tension between physical and spiritual resurrection that is unresolved. Paul does not clarify what elements make up the resurrected body, nor is he clear about what continuity (or lack thereof) exists between our perishable bodies and bodies in the resurrection. Moreover, Paul's statement in 1 Cor 15.50 that 'flesh and blood cannot inherit the kingdom of God' further complicates early Christian understandings of resurrection and its form. As such, 15.50 stands at the centre of early Christian debate about resurrection as apologists struggle to affirm the value of flesh and blood as the medium of salvation while accepting its problematic character, both spiritual and somatic.

However, before engaging the question of how early Christians attempt to solve the problems caused by Paul's words, we turn first to how they use this portion of 1 Corinthians 15 within their writings.

\section{Early Christian Use of 1 Cor 15.50-58}

It is worth noting that the focus on resurrection in early Christian writings occurs within a culture and a time in which understandings of the soul, body, spirit, and flesh took different forms, including Graeco-Roman philosophical, Jewish, and Valentinian and so-called 'gnostic' views. Thus, when early Christians use the phrase flesh and blood from 1 Cor 15.50, the flesh and blood to which they refer has at least four meanings: the elements that make up the human body, ${ }^{10}$ Christ's human body and

\footnotetext{
${ }^{10}$ See, for example, Irenaeus, Haer. 5.1.4; Tertullian, Res. 49; Origen, Princ. 2.10.2-3 and Fr. Ps. 1.5; Peter of Alexandria, Res. 4.4.
} 
nature, ${ }^{11}$ Christ's bodily presence in the elements of the Eucharist, ${ }^{12}$ and the words and deeds associated with the body and especially the flesh. ${ }^{13}$ These different understandings of Paul's statement about flesh and blood mean that phrases from 1 Corinthians 15 are adapted to support a range of arguments. In other words, early Christians embrace each of these meanings as they use excerpts from 1 Cor 15.50-58 to strengthen their own writings.

\section{Gospel of Philip}

Anonymous pre-Nicene texts, especially those associated with the Valentinians, offer various examples of how 1 Cor $15.50-58$ was used by some of the earliest Christian writers. Within these texts, $15.50-58$ features in arguments that separate the flesh from immortality, advocate the triumph of spirit over flesh, and contend that immortality and resurrection can be realized in the present. As White concludes: 'Some of the language of the Pauline corpus was fertile ground for the Valentinians' and this is especially true of 1 Corinthians $15 .^{14}$

The Gospel of Philip, for example, is a third-century Nag Hammadi text containing numerous NT phrases and at least two excerpts from 1 Cor 15.50. This text

\footnotetext{
${ }^{11}$ See Irenaeus, Haer. 5.13.1; 5.14.1-2; Tertullian, Res. 49; Pamphilus, Apologia pro Origene, 128.

${ }^{12}$ See Gos.Phil. 56.26-57.21; Irenaeus, Haer. 5.2.2-5.3.2.

${ }^{13}$ See Irenaeus, Haer. 5.13.3-5.13.5; 5.9.4; 5.14.4; Tertullian, Res. 49.11; Marc. 5.14.

${ }^{14}$ B. L.White, Remembering Paul: Ancient and Modern Contests over the Image of the Apostle (Oxford: Oxford University Press, 2014) 37.
} 
suggests that the only reason other Christians espouse bodily resurrection is because they fear nakedness and existence apart from a physical body. In other words, some are afraid that they might rise naked. Because of this they wish to rise in the flesh and do not know that it is those who wear the [flesh] who are naked. Flesh [and blood shall] not inherit the kingdom [of God] (1 Cor 15.50). What is this what will not inherit? This which is on us. But what is this, too, which will inherit? It is that which belongs to Jesus and his blood. Because of this, he said, he who does not eat my flesh and drink by blood has not life in him (John 6.53). ${ }^{15}$

Balancing references to 'flesh' and 'blood' in 1 Corinthians 15 and John 6, resurrection is described as an experience in this present world of the sacrament. This means, in the words of John's Gospel, that those who have not partaken of the flesh and blood of Jesus have no life in them. ${ }^{16}$ Presenting the situation to be much more complex than a rejection or acceptance of the doctrine of fleshly resurrection, the Gospel of Philip appears to promote both positions and ends up with a solution between these two possibilities, arguing that resurrection is available to Christians in the sacrament of the Eucharist. ${ }^{17}$ The subject of rising for the Gospel of Philip is the

${ }^{15}$ Gos.Phil. 56.26-57.21 (Layton). The Gospel of Philip is a Coptic text and this study relies on the translation provided in B. Layton, ed., The Gnostic Scriptures: A New Translation with Annotations and Introductions (ABRL; New York: Doubleday, 1995). For Tertullian's reply to this argument about nakedness, see Res. 42.

${ }^{16}$ K. L. Gaca and L. L. Welborn, Early Patristic Readings of Romans (New York: T\&T Clark, 2005) 116.

${ }^{17}$ M. J. Olson, Irenaeus, the Valentinian Gnostics, and the Kingdom of God (A.H. Book V): The Debate about 1 Corinthians 15:50 (Lewiston, N.Y.: Mellen Biblical Press, 1992) 32-3. 
flesh and blood of Jesus and therefore, the author concludes that one should not have any fear about rising naked, because those who have received Jesus in the sacrament are clothed with his flesh and blood. ${ }^{18}$ In other words, attempting to describe the logical effects of 1 Cor 15.50, the Gospel of Philip argues that the flesh and blood that will be raised (and clearly not all of flesh and blood is to be raised) is that which belongs to Christ and has been transformed by the Eucharist.

\section{Irenaeus}

Similar to the Gospel of Philip, Irenaeus, the Bishop of Lyons in the second century, also struggles with how to interpret 1 Cor 15.50 in his apologetic work Against Heresies. However, he is clear that those who interpret this text like the Valentinians and who do not believe in the resurrection of the flesh present an argument which he sees 'not simply as a denial of the humanity of Jesus, but as a denigration of the flesh, which . . . is increasingly seen as the instrument of salvation itself. ${ }^{19}$ Irenaeus is particularly concerned that his opponents take this excerpt from Paul at face value, 'without having understood the Apostle's meaning, or examined critically the force of the words, but holding fast to the mere expressions by themselves, they die in consequence of their influence, overturning as far as in them lies the entire

\footnotetext{
${ }^{18}$ See A.H.C. van Eijk, 'The Gospel of Philip and Clement of Alexandria: Gnostic and Ecclesiastical Theology on the Resurrection and the Eucharist', VC 25 (1971) 94 120 , at 96.

${ }^{19}$ G.W. MacRae, 'Why the Church Rejected Gnosticism', Jewish and Christian SelfDefinition (ed. E.P. Sanders, et al.; London: SCM Press, 1980-1982) 126-33, at 133.
} 
dispensation of God (universam dispositionem Dei). ${ }^{, 20}$ For Irenaeus, 1 Cor 15.50 causes a massive problem because for resurrection of the flesh to be possible, he must affirm what the text appears explicitly to deny. In order to make this move, therefore, he must demonstrate both why his opponents' understanding is faulty and how he offers a more critical and thus, by his reasoning, correct examination of Paul's words. He begins with the claim that his opponents' interpretation of 1 Cor 15.50 does not work because of its understanding of flesh apart from the kingdom of God. He must then redefine the phrase 'flesh and blood,' arguing that Paul was not speaking literally when he wrote 'flesh and blood cannot inherit the kingdom of God. ${ }^{, 21}$ Rather, flesh and blood, refer not only to the physical nature of humankind, but by flesh and blood Paul also means those who reject God's Spirit and do not have the Spirit of God within them. He writes,

In order that we may not lose life by losing that Spirit which possesses us, the Apostle, exhorting us to the communion of the Spirit (ad Spiritus communicationem), has said according to reason in those words already quoted, that flesh and blood cannot inherit the kingdom of God (1 Cor 15.50: quoniam caro et sanguis regnum Dei possidere non possunt). Just as if he were to say, do not err; for unless the word of God (verbum Dei) dwells within and the Spirit of the Father is in you, and if you shall live frivolously and carelessly as if you were only this flesh and blood, you cannot inherit the kingdom of God. ${ }^{22}$

\footnotetext{
${ }^{20}$ Irenaeus, Haer. 5.13.2 (SC 153).

${ }^{21}$ Irenaeus, Haer. 5.13 .3 (SC 153).

${ }^{22}$ Irenaeus, Haer. 5.9.4 (translation adapted from SC 153 and Roberts). See also
} Haer. 5.9.1-5.9.3. 
While his opponents use 15.50 to conclude that Paul really meant physical flesh and blood cannot inherit the kingdom of God and are therefore inferior to the divine nature, Irenaeus takes an opposing view. Instead of interpreting flesh and blood as physical attributes of the resurrection body, Irenaeus equates flesh and blood to actions of frivolous and careless living. With this new understanding of terms, Irenaeus is clear that the interpretation of his opponents is not logical for they 'allege that this passage refers to the flesh strictly so called and not to fleshly works, as I have pointed out. $^{, 23}$

In this way, Irenaeus turns a simple phrase — flesh and blood —into an ethical injunction, reading beyond what is written to enjoin Christians to live not as if the Spirit is separate from flesh and blood but as if all of life is integrated. Irenaeus's interpretation of 1 Corinthians 15 ends up being two-fold: on the one hand, flesh and blood are understood as fleshy desires and works in need of the Spirit of God and, on the other, flesh and blood are essential elements of God's creation and are saved though Christ. ${ }^{24}$ Irenaeus thus confirms that those who interpret 1 Cor 15.50 by separating flesh and blood from salvation and the Spirit, deny the reality that flesh itself is an instrument of salvation and, in his words, the very handiwork of God. ${ }^{25}$

${ }^{23}$ Irenaeus, Haer. 5.13 .3 (SC 153).

${ }^{24}$ O. Lehtipuu, "“Flesh and Blood Cannot Inherit the Kingdom of God:” The Transformation of the Flesh in the Early Christian Debates Concerning Resurrection', Metamorphoses: Resurrection, Body and Transformative Practices in Early

Christianity (ed. T. Karlsen Seim and J. Økland; Berlin: De Gruyter, 2009) 147-68, at 155. See also Irenaeus, Haer. 5.2.2.

${ }^{25}$ Irenaeus, Haer. 5.9.1. (SC 153). 


\section{Tertullian}

Writing at the beginning of the third century, Tertullian is equally distressed by the words of 1 Cor 15.50 and their explicit and problematic denial of a fleshly resurrection. Taking a different approach from Irenaeus initially, he writes that Paul's words in 1 Cor 15.50 are ambiguous in terms of flesh, blood, and resurrection so that no one, and especially not his opponents, can claim fully to understand what Paul meant. He asks sarcastically, pointing out the folly of such assured conclusions, 'is there any now who has risen again, except a heretic (haereticus)? ${ }^{26}$ Nevertheless, like the Gospel of Philip's author and Irenaeus, Tertullian then attempts to define what he thinks Paul means by flesh and blood in 15.50 since taking these words only at face value must be wrong. For Tertullian, the flesh and blood about which Paul writes are not the elements that make up the corrupted state, but they are the subjects of corruption. In other words, the disinheritance of flesh and blood found in 1 Cor 15.50 refers only to their works and discipline, not to their substance. ${ }^{27}$ In this way, the flesh and blood which do not inherit the kingdom of God are actually, 'the works done in the substance of the flesh, alienating us from the kingdom of God. ${ }^{28}$

In a slightly more developed argument than Irenaeus, Tertullian writes that Paul intended 'flesh and blood cannot attain the kingdom of God (1 Cor 15.50: caro et sanguis regnum Dei non consequentur), not passing sentence on the substance (substantia), but on its works (opera), and because while still in the flesh we are

\footnotetext{
${ }^{26}$ Tertullian, Res. 22.11 (CCL 2). See also Res. 24.7.

${ }^{27}$ J. Daniélou, A History of Early Christian Doctrine: The Origins of Latin

Christianity (London: Darton, Longman \& Todd, 1977) 3:160.

${ }^{28}$ Tertullian, Res. 49.11 (CSEL 47).
} 
capable of not committing these, they will be accounted to the guilt not of the substance but of our conduct. ${ }^{29}$ For Tertullian, judgement ultimately is not of the physical substance of flesh and blood but the works of flesh and blood which lead to its separation and exclusion from the kingdom of God. Against Marcion, he insists that the focus of 15.50 is first and foremost about the works and attributes of flesh and blood because the question of their substance is not up for debate.

In this brief glimpse at three early Christian writers and their struggle to interpret Paul's language in 1 Corinthians 15.50, both the form of resurrection and the power and unity of God are at stake. Setzer is clear that as early Christian understanding about resurrection of the flesh develops, it becomes 'more explicitly articulated as circumstances demand. The doctrine carries several ideas in its wake: the power of God, the composite quality of a human as a unity of body and soul, the demand for ultimate justice, the testimony from Scripture, and the legitimacy of those who preach resurrection. ${ }^{30}$ However, the struggle to interpret 1 Cor 15.50 by three different early Christian writers also highlights how the difficulties posed by Paul's language lead not only to three different conclusions but also to three different understandings of flesh, blood, and the kingdom of God. Given that, as Tertullian states, a right

${ }^{29}$ Tertullian, Marc. 5.14 (CCL 1 and Evans). See also C.F.D. Moule, 'St Paul and Dualism: The Pauline Conception of Resurrection', NTS 12 (1966) 106-23, at 108, where he writes that physical resurrection for Tertullian is ultimately 'a moral, not physical or quasi-physical concern.'

${ }^{30}$ C. Setzer, Resurrection of the Body in Early Judaism and Early Christianity: Doctrine, Community, and Self-Definition (Boston: Brill Academic Publishers, 2004) 154. 
interpretation of 1 Cor 15.50 is 'in very truth the gist of the whole question, ${ }^{31}$ Paul's language and conflicting interpretations of it posed serious problems to the developing doctrine of resurrection and especially fleshly resurrection. Thus, early Christians needed to engage other scriptural texts to defend their argument for resurrection of the flesh and, in this context, Lazarus and the state, and in particular the smell, of his body are essential.

\section{The Necessity of Lazarus}

In order to defend both their interpretation of 1 Cor 15.50 and the doctrine of fleshly resurrection, early Christian writers such as Irenaeus, Tertullian, and later Augustine, turned from Paul's letters to gospel stories of healing and resurrection. While the death and resurrection of Jesus are certainly central to arguments for resurrection of the flesh, early Christians needed more evidence than Jesus to counter both internal skeptics and external opponents. ${ }^{32}$ Thus, what we find in many early Christian writings is a catena of scriptural proof-texts about resurrection, which they argue prefigure and confirm a resurrection of the flesh. In particular, the story of Jesus raising Lazarus from the dead in John 11, and especially $11.38-44$, is used by early Christians to justify their belief in bodily resurrection. It is notable that excerpts from this story may be found in the arguments of almost 30 authors writing before the fifth

${ }^{31}$ Tertullian, Res. 49.1 (CCL 2).

${ }^{32}$ See R. M. Jensen, Baptismal Imagery in Early Christianity: Ritual, Visual, and Theological Dimensions (Grand Rapids, Mich.: Baker Academic, 2012) 149; C. Moss, 'Heavenly Healing: Eschatological Cleansing and the Resurrection of the Dead in the Early Church', JAAR 79 (2011) 991-1017, at 1004. 
century. ${ }^{33}$ Within these texts, the story of Lazarus's raising is read as an historical event where his flesh and sinews were reconstructed in the tomb by the call of God the Son (as in the works of Irenaeus and Amphilochius). It is also read as an allegory for the way Christians may be unbound from their sins by the call of Jesus (as found in the writings of Gregory of Nyssa). Moreover, the raising of Lazarus becomes the focus for a number of early Christian homilies, with examples surviving from as early as the third century. ${ }^{34}$

We must note that it is not until later in this time period, in the works of those such as Methodius and later Augustine, that early Christians begin to question this parallel between Lazarus and the resurrection of the flesh and the - in hindsight, obvious - reality that Lazarus, while raised, did die again. But it is also worth noting that unlike the other stories of resurrection performed by Jesus-Jairus's daughter and

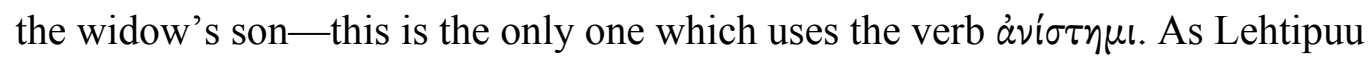
determines, it is more difficult to distinguish between the resurrection of Jesus and that of Lazarus when the verbs used to describe each are the same, 'especially as a little later in the narrative, the evangelist refers to Lazarus as the one "whom Jesus

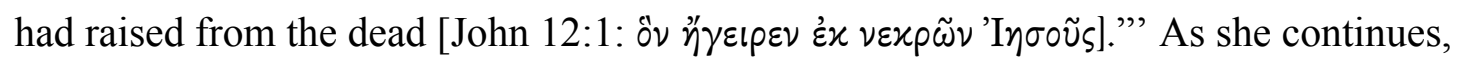
'this is exactly the same expression that is commonly used of Jesus in NT writings; compare "Jesus Christ of Nazareth ... whom God raised from the dead [Acts 4:10: ôv

${ }^{33}$ This includes Ambrose, Amphilochius, Adamantius, Athanasius, Cyril of Jerusalem, Epiphanius, Gregory of Nazianzus, Gregory of Nyssa, Hippolytus, Irenaeus, Methodius, Origen, Pamphilus, and Tertullian.

${ }^{34}$ See J. H. Barkhuizen, 'Homily 3 of Amphilochius of Iconium: On the Four-day \{Dead\} Lazarus: An Essay in Interpretation', Acta Patristica et Byzantina 5 (1994) 111, at 1 (see n. 1 for other examples of early homilies on Lazarus's resurrection). 


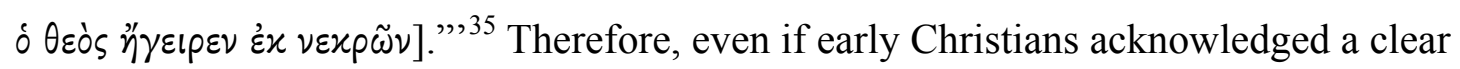
difference between Jesus and Lazarus and their resurrections in that Lazarus did die again, this is not the crucial point. Rather, what is central is 'the equation of resurrection with the revival of a dead body. ${ }^{36}$ Furthermore, as Augustine is clear, 'although according to the gospel history, we have full confidence of the resurrection of Lazarus (resuscitatum Lazarum plena fide teneamus), nevertheless I have no doubt that the event has allegorical significance (allegoria significare), as well. Yet when facts are allegorized, we don't lose our belief in them as fact. ${ }^{37}$

Therefore we find that for early Christian writers, the resurrection of Lazarus serves as a topos for the resurrection of both Christ and humankind ${ }^{38}$ as it foreshadows the Easter narrative where 'stones seal tombs; women mourn; and the raised cast off their linen winding sheets. ${ }^{39}$ Moreover, this story of resurrection is different from the other two resurrection miracles performed by Jesus not only in terms the verb used to describe the actual event ( $\varepsilon \gamma \varepsilon i \rho \omega$ vs. $\left.\alpha^{\prime} v i \sigma \tau \eta \mu \iota\right)$ but also because Jairus's daughter and the widow's son are raised soon after their deaths. This is significant firstly because as Tertullian suggests, skeptics and opponents argue that these two raisings were merely resuscitations, and second because the time period of four days for Lazarus, after which a number of Jewish sources attest that the soul

${ }^{35}$ O. Lehtipuu, Debates over the Resurrection of the Dead: Constructing Early

Christian Identity (Oxford: Oxford University Press, 2015) 29-30.

${ }^{36}$ Lehtipuu, Debates, 30.

${ }^{37}$ Augustine, Div. quaest. LXXXIII 65 (CC 44A).

${ }^{38}$ Barkhuizen, 'Amphilochius,' 2.

39 Jensen, Baptismal Imagery, 150. 
would have left the body, places this story into another category. ${ }^{40}$ Thus, for early Christian writers, a focus on the four days and on the smell of the body's decay was necessary to show that Lazarus was not merely resuscitated but resurrected.

With this introduction and context, the remainder of this article will concentrate on three early Christian writers-Irenaeus, Tertullian, and Augustineand their use of Lazarus's body to affirm what 1 Cor 15.50 seems explicitly to deny: bodily resurrection. This is especially clear in the writings of Irenaeus and Tertullian as both need Lazarus's dead and risen body to argue that the so-called gnostic interpretation of Paul's words against the flesh in 1 Cor 15.50 is mistaken and the condemnation of the flesh is not what Paul actually intends. ${ }^{41}$

\section{Irenaeus}

We know from the brief glimpse at the arguments concerning resurrection and 1 Corinthians 15 above that early Christians were writing in a time period when language and understandings about bodily resurrection were not universal. Paul's statement in 1 Cor 15.50 that 'flesh and blood cannot inherit the kingdom of God'

${ }^{40}$ See R. Brown, The Gospel According to John I-XII (ABS 29; New Haven, Conn.: Yale University Press, 1995) 434; Barkhuizen, ‘Amphilochius,' 10 n. 27; see also Leontius Presbyter, Hom. 2.335-337; Lev. Rab. 18.1; Eccl. Rab. 12.6; m. Yebam. 16.3; and Sem. 8, Rule 1. Keener is not convinced that this belief was as widespread as Brown and others claim; see C. S. Keener, The Gospel of John: A Commentary (Peabody, Mass.: Hendrickson, 2003) 841 n. 63.

${ }^{41}$ G. G. Stroumsa, 'Caro salutis cardo: Shaping the Person in Early Christian Thought', HR 30 (1990) 25-50, at 43. 
means that some refuse to consider anything but a spiritual resurrection in a 'spiritual body' (1 Cor 15.44). In response, Irenaeus dedicates the fifth book of his Against Heresies to refuting claims that bodily resurrection is not possible due to the inherent evil of the material, fleshly world. Within this chapter, the story of Lazarus's resurrection and the restoration of his body serves as a rebuttal to the anti-materialism of his so-called gnostic opponents. More specifically, this story from John's gospel enables Irenaeus to argue that just as Jesus restored people who were dead to life in their bodies, so it will be at the resurrection of all. However, as discussed above, 1 Cor 15.50 presents enormous difficulties to Irenaeus's argument for bodily resurrection, especially when this text is used by his opponents not only to annoy but 'to point out that the handiwork of God is not saved. ${ }^{42}$ Thus, he looks both to Jesus's own make up as well as John's gospel to show why this understanding of Paul by his opponents is wrong. He begins with a focus on Christ as he writes that, inasmuch as the Apostle has spoken against the very substance of flesh and blood, that it cannot inherit the kingdom of God (1 Cor 15.50; carnis et sanguinis dixit Apostolus non possidere eam regnum Dei), the same Apostle has everywhere adopted the term flesh and blood with regards to the Lord Jesus Christ, partly indeed to establish his human nature ... and partly that he might confirm the salvation of our flesh (salute carnis nostrae confirmaret), for if the flesh were not in a position to be saved, the word of God would not have become flesh (nequaquam Verbum Dei caro (actum esset) ${ }^{43}$

\footnotetext{
${ }^{42}$ Irenaeus, Haer. 5.9.1 (SC 153; Roberts).

${ }^{43}$ Irenaeus, Haer. 5.14.1 (translation adapted from SC 153 and Roberts).
} 
That Christ himself took on flesh and blood confirms the integrity and salvation of the flesh for Irenaeus. But if this is not enough to convince his opponents that Paul does not actually mean what he appears to state in 15.50 , Irenaeus turns to the acts of healing performed by Jesus and asks why Jesus would heal physical bodies throughout his life and ministry if flesh and blood were not valued or saved. ${ }^{44}$ He asks directly,

what was [Jesus's] object in healing different portions of the flesh and restoring them to their original condition, if those parts which had been healed by him were not in a position to obtain salvation? For if it was merely a temporary benefit which he offered, he granted nothing of importance to those who were the subjects of his healing. ${ }^{45}$

It is at this point that Irenaeus singles out Lazarus as he asks, 'Lazarus, who had lain four days in the tomb, in what [body] did [he] rise again? ${ }^{46}$ And his answer, which includes all those whom Jesus raised in his life and ministry, is clear:

In the same, no doubt, in which they had also died. For if it were not the very same, then certainly those same individuals who had died did not rise again. For [the Scripture] says ... He called Lazarus, with a loud voice saying, Lazarus come forth. And he that was dead came forth, his feet and hands bound with cloth. This was symbolic of that man who had been bound in sins. And therefore, the Lord said, unbind him and let him go. Since, therefore, those who were healed were made whole in those members which had in times past been afflicted; and the dead rose in identical bodies, their limbs and bodies receiving health, so also that life which was granted by the Lord, who prefigures eternal things by temporal, shows that it is he

\footnotetext{
${ }^{44}$ Irenaeus, Haer. 5.13.1 (SC 153).

${ }^{45}$ Irenaeus, Haer. 5.12.6 (SC 153).

${ }^{46}$ Irenaeus, Haer. 5.13.1 (SC 153).
} 
who is himself able to extend both healing and life to his handiwork, that his words concerning its future resurrection may also be believed. ${ }^{47}$

While it might appear from the words of 1 Corinthians 15 that flesh and blood will not be a part of the resurrection and that resurrection is solely in a spiritual but not physical body, for Irenaeus, the reality that Jesus raised Lazarus from the dead in his body prefigures the resurrection at the end of time and makes clear that God will raise people from the dead in their physical bodies. Lazarus - who he stresses was in the tomb for four days and thus was dead - must have been resurrected in the same physical body or he could not have been the same person. For Irenaeus, the resurrected body is not simply a resuscitated corpse ${ }^{48}$ but rather, as Paul states in 1 Cor 15.53 , the resurrected body is immortal, incorruptible, and changed. Yet it is still flesh and blood because Christ 'had himself, therefore, flesh and blood (carnem et sanguinem), recapitulating (recapitulans) in himself not a certain other, but the original handiwork of the Father seeking that thing which had perished. ${ }^{, 49}$ Lazarus's resurrection is evidence that even though the body decays after death, decomposing flesh can be restored and glorified at God's command, just as, in the words of Paul, the resurrection body will be glorified (1 Cor 15.43). In this way, Christ himself who had flesh and blood, recapitulates or sums up in his very being not something other than himself but, through his death and resurrection, saves what Irenaeus calls the 'original handiwork' of God: flesh and blood. ${ }^{50}$

\footnotetext{
${ }^{47}$ Irenaeus, Haer. 5.13.1 (SC 153).

${ }^{48}$ Irenaeus, Haer. 5.15.1 (SC 153).

${ }^{49}$ Irenaeus, Haer. 5.14.2 (SC 153).

${ }^{50}$ Irenaeus, Haer. 5.14.2 (SC 153).
} 


\section{Tertullian}

Like Irenaeus, who focuses on the four-day dead body of Lazarus to prove his point concerning the problematic text of 1 Cor 15.50 , Tertullian concentrates on the reality that it is the flesh and not the soul that decomposes upon death. In fact, Tertullian does not believe that one can separate flesh and blood from the soul. Therefore, even though 1 Cor 15.50 reads that 'flesh and blood cannot inherit the kingdom of God,' as with Irenaeus, right doctrine trumps Tertullian's opponents' who take this Pauline phrase at face value. He goes so far as to call his Valentinian opponents 'modern Sadducees ${ }^{51}$ whose denigration of the flesh and denial of bodily resurrection is evidently incorrect since a resurrection that does not include flesh and blood with the soul is only 'half a resurrection' because 'if God raises not whole humans, God raises not the dead. ${ }^{, 52}$

It is from this place that Tertullian asks why Paul would have been so concerned with the nature of the resurrection body if the body were not part of resurrection. He concludes that resurrection must be defined 'as corporal, since it is with the quality of bodies that the discussion is concerned. ${ }^{53}$ Here, Lazarus plays a prominent role in Tertullian's exegesis of 1 Corinthians and his doctrine of resurrection. In fact, for Tertullian, Lazarus's resurrection and the restoration of his decaying flesh is 'the pre-eminent example of resurrection (praecipuo resurrectionis exemplo). ${ }^{54}$ He writes that Lazarus is the one whose

\footnotetext{
${ }^{51}$ Tertullian, Carn. Chr. 1.1 (CCL 2).

${ }^{52}$ Tertullian, Res. 2.2 and 57 (CCL 2).

${ }^{53}$ Tertullian, Res. 48 (CCL 2).

${ }^{54}$ Tertullian, Res. 53.3 (CCL 2).
} 
flesh lay prostrate in weakness, the flesh was almost putrid in its dishonour, the flesh smelled in corruption, and yet it was as flesh that Lazarus rose again, with his soul, indeed. But that soul was incorrupt, as no one had bound it with linen bands, no one had placed it in the grave, no one had perceived it to smell, no one had seen it sown four days before. Everything that Lazarus was, everything that happened at his death, is indeed what the flesh of all humankind is still experiencing, but no one's soul is experiencing it. ${ }^{55}$

The example of Lazarus proves for Tertullian that what is sown, in the words of 1 Corinthians 15 , is the body since 'certainly nothing else rises again but what is sown, nothing else is sown but what is dissolved in the ground, and nothing else is dissolved in the ground but flesh. ${ }^{56}$ As Tertullian is clear, the soul is not what decays in death but, as with the example of Lazarus, 'whose flesh was not composed of soul, any more than his soul was turned into flesh, ${ }^{57}$ it is the body which is perishable and corruptible. He asks, 'what body is uninjured, when it is dead, when it is cold, when it is ghastly, when it is stiff, when it is a corpse? . . Thus, for a dead man to be raised again, amounts to nothing short of his being restored to his whole condition. ${ }^{58}$ The body which Paul declares to be sown perishable and raised imperishable cannot be the soul but must be the physical body. Resurrection cannot be applied to that which cannot fall or decay, like the soul, and thus resurrection must be applied to the flesh. ${ }^{59}$ For Tertullian, 1 Cor 15.50 detached from the rest of Paul's writing on resurrection is

\footnotetext{
${ }^{55}$ Tertullian, Res. 53.3 (CCL 2).

${ }^{56}$ Tertullian, Res. 52 (CCL 2).

${ }^{57}$ Tertullian, Carn. Chr. 12 (CCL 2).

${ }^{58}$ Tertullian, Res. 32 and 57 (CCL 2).

${ }^{59}$ Tertullian, Res. 18.5-8 (CCL 2).
} 
wrong since Paul 'has wrought with all his powers of doctrine for the resurrection not of the soul, but of the flesh ${ }^{60}$ and even though this flesh may change, 'change is one thing, and destruction is another. ${ }^{61}$ For God, he argues, 'is quite able to remake what God once made. ${ }^{62}$ Therefore, 'our flesh shall remain even after the resurrection, so far indeed susceptible of suffering, as it is the flesh, and the same flesh; but at the same time impassible, inasmuch as it has been liberated by the Lord for the very end and purpose of no longer being capable of enduring suffering. ${ }^{63}$

He is increasingly dramatic as he writes that of course resurrection is of the flesh, for as the example of Lazarus shows, 'God forbid that God should abandon to eternal destruction the work of his own hands, the product of his own skill, the receptacle of his own breath, the queen of his own creation. ${ }^{64}$ Thus, for Tertullian, 'when the resurrection takes effect, it will be possible to be changed, converted, and reformed, while the substance of flesh remains unimpaired. ${ }^{65}$ What rises is the site of our decay and rotting for, in the words of Paul, perishable must put on imperishability (1 Cor 15.53). With the examples of Lazarus and Christ himself, Tertullian concludes that it is not the soul or the spirit but the flesh which 'is the axis of salvation (caro salutis est cardo) ${ }^{, 66}$ and it is this resurrection, that of the flesh, which is 'the Christian's confidence. ${ }^{67}$

\footnotetext{
${ }^{60}$ Tertullian, Res. 53.6 (CCL 2).

${ }^{61}$ Tertullian, Res. 55.1 (CCL 2).

${ }^{62}$ Tertullian, Res. 32 and 57 (CCL 2).

${ }^{63}$ Tertullian, Res. 57 (CCL 2).

${ }^{64}$ Tertullian, Res. 6 (CCL 2).

${ }^{65}$ Tertullian, Res. 55 (CCL 2).

${ }^{66}$ Tertullian, Res. 8.2 (CCL 2).
} 


\section{Augustine}

As we move into the fourth century, we encounter a significant shift in the role that the body of Lazarus plays in determining a correct interpretation of 1 Corinthians 15 . In the Catechetical Lectures of Cyril of Jerusalem and the writings of Augustine, the raising of Lazarus still points to an argument for resurrection of the physical body. ${ }^{68}$ But, as foreshadowed by Irenaeus, this Johannine text also includes an allegorical element where the stench of the body is equated to one's spiritual state of sin, and writers such as Ambrose and Augustine draw out the moral implications of such a story of resurrection. ${ }^{69}$ While Irenaeus and Tertullian primarily concentrate on using Lazarus's body to defend an interpretation of 1 Corinthians 15 that allows for a fleshly resurrection, Augustine's approach is rather different. Though his interpretation of John 11 focuses significantly on this story as an allegory of the soul's progress to divine life ${ }^{70}$ he recognizes that Lazarus did not rise allegorically and thus also focuses on the physical aspects of this resurrection.

Following the words of Paul in 1 Cor 15:44, Augustine believes that the resurrection body will be a spiritual body. Nevertheless, he is quick to clarify that 'the flesh will then be spiritual, and subject to the spirit; but it will still be flesh and not spirit. ${ }^{, 71} \mathrm{He}$ 'integrates the physicalist and the spiritual traditions of the resurrection

\footnotetext{
${ }^{67}$ Tertullian, Res. 1.1 (CCL 2).
}

${ }^{68}$ See Cyril of Jerusalem, Catech. 18.1-21.

${ }^{69}$ See Ambrose, Paen. 2.7.58 and Augustine, Tract. Ev. Jo. 49.2-3, 20-25.

${ }^{70}$ Augustine, Tract. Ev. Jo. 49.

${ }^{71}$ Augustine, Civ. 22.21. 
by insisting on both ${ }^{72}$ and he does this in at least two different ways. On the one hand, Augustine argues that the make up of the resurrection body is like a statue which has been melted and recast: the same material will be in the new statue, but it might be in different locations. ${ }^{73}$ This, he writes, is also the case with the flesh and spirit at the resurrection. Both will be raised, but they will be changed and recast from corruptible into incorruptible. On the other hand, Augustine's interpretation of 1 Cor 15.50 leads him to insist on the physicality of the resurrected body. He gets around the troublesome words of 15.50 that 'flesh and blood will not inherit the kingdom of God' by claiming, similar to Tertullian, that the corruptibility of the flesh would not be raised, but the substance of the flesh would. ${ }^{74}$ He even goes so far as to explain how lost hair and nail clippings would be a part of the resurrection body without this body being an "ugly, monstrous deformity. ${ }^{75}$ Any further details about how this works, however, are a mystery since, he writes, 'no experience that we have yet had enables us to know what the nature of that spiritual body and the extent of its grace will be; and so it would, I fear, be rash to offer any description of it. ${ }^{, 76}$

Where Lazarus comes into the picture for Augustine is significant, and he begins one of his homilies on the Gospel of John by declaring that 'among all the miracles performed by our Lord Jesus Christ, the resurrection of Lazarus holds a

\footnotetext{
${ }^{72}$ T. Nichols, Death and Afterlife: A Theological Introduction (Grand Rapids, Mich.: Brazos Press, 2010) 65.

${ }^{73}$ Augustine, Enchir. 89.

${ }^{74}$ Augustine, Retract. 2.3.

${ }^{75}$ Moss, "Heavenly Healing," 1009. See also Augustine, Civ. 22.19.

${ }^{76}$ Augustine, Civ. 22.21.
} 
foremost place. ${ }^{, 77} \mathrm{He}$ is clear that, 'a man was raised up by him who made humankind, for he is the only one of the Father by whom, as you know, all things were made. . . . It is a greater deed to create humankind than to raise them again from the dead. Yet he deigned both to create and to raise again; to create all, to resuscitate some. ${ }^{, 78}$ While he uses the word 'resuscitate' to describe the raising of Lazarus, Augustine is quick to clarify the connection with resurrection and the flesh for, the Lord Jesus raised a dead man to life and that is sufficient to let you know that, were he so pleased, he might raise all the dead to life. ... For while you have heard that by a great miracle he raised one from the tomb who had been dead four days, the hour is coming, as he himself says, in which all who are in the graves shall hear his voice and shall come forth. He raised one who was putrid, and yet in that putrid carcass there was still the form of limbs. But at the last day he will by a word reconstitute ashes into human flesh. ${ }^{79}$

Augustine's focus on the decay and decomposition of Lazarus's body foreshadows, for him, the resurrection of all. ${ }^{80}$ While Lazarus was called from death to life by the

\footnotetext{
${ }^{77}$ Augustine, Tract. Ev. Jo. 49.1.

${ }^{78}$ Augustine, Tract. Ev. Jo. 49.1.

${ }^{79}$ Augustine, Tract. Ev. Jo. 49.1.

${ }^{80}$ Lazarus, however, also serves another function since, unlike earlier Christian writers who did not worry about the fact that Lazarus, though raised, died again, Augustine wants to ensure that the resurrection of Lazarus and that of Jesus are not confused as the same kind of rising. Thus, while Lazarus's death and rising prefigure our resurrection in the flesh, this resurrection of the body is 'not a resuscitation such as some have had, who came back to life for a time and died again, but a resurrection to eternal life, as the body of Christ himself rose again' (Augustine, Enchir, 84. See
} 
word of Christ, so Augustine uses the words of Jesus to declare that all who are in the graves shall 'hear his voice and shall come forth. ${ }^{, 81}$ Moreover, contrary to 1 Cor 15.50, flesh and blood can inherit the kingdom of God for just as Lazarus's 'putrid carcass' was reformed in his rising, so by the call of Christ, our bodies will be reformed not into a spiritual body, but 'into human flesh. ${ }^{, 82}$

\section{Concluding Remarks}

For early Christian writers such as Irenaeus, Tertullian, and Augustine, the nature of Paul's language in 1 Corinthians 15 and especially his statement about flesh and blood in 1 Cor 15.50 pose serious problems for their understanding of the place of the flesh in the resurrection. Their opponents, such as Celsus, call a hope in fleshly resurrection 'the hope of worms' and ask in horror, 'what sort of human soul would have any desire for a body that has rotted? ${ }^{83}$ Furthermore, such opponents are clear

also John Chrysostom, Hom. Jo. 40.2 and Cyril of Jerusalem, Catech. 18.1). Augustine even goes so far in his Letter to Deogratias to clarify that the words of the creed concerning resurrection 'to everlasting life' were added so as to prevent anyone from drawing the conclusion that the resurrection of all would be like that of Lazarus rather than that of Christ (Augustine, Ep. 102.2-7 [CSEL 34]; see also J. N. D. Kelly, Early Christian Creeds (London: Longman, 1972 ${ }^{3}$ ) 387).

${ }^{81}$ Augustine, Tract. Ev. Jo. 49.1.

${ }^{82}$ Augustine, Tract. Ev. Jo. 49.1.

${ }^{83}$ Origen, Cels. 5.14 (SC 147). 
that flesh is, in the words of Marcion, 'full of dung (stercoribus infersam) ${ }^{, 84}$ and its resurrection is 'both revolting and impossible. ${ }^{85}$ As the opponents of early Christians hurled insults and philosophical arguments to counter a belief in resurrection of the flesh, and as they used the words of Paul in 1 Cor 15.50 to support their claims, early Christians sought to reclaim the words of Paul as their own and mounted ingenious arguments and exegesis to do so. For even though Paul speaks of the resurrection in terms of a 'spiritual body' and writes the problematic words in 15.50, early Christian writers stressed that Christ lived in the flesh, rose in the flesh, and so too will all Christians (or, for those like Tertullian who argue for a resurrection for judgement, all people). Stressing the unity of the human person, of Christ, and God's power and justice, the resurrection of the flesh was a necessity.

However, anthropological and Christological arguments were not enough for early Christians to claim both the words of Paul and a fleshly resurrection. They needed scriptural support for their exegesis of 1 Corinthians 15 and they found this support in John 11 and the resurrection of Lazarus. While their opponents were horrified at the idea of the body rotting and decomposing, for early Christians it was the very rotting, oozing body of the four-day dead Lazarus that served as proof that the flesh is precisely what God promises to raise. Thus, as we have seen, these early Christians writers did not shy away from details of the body's decay, showing no revulsion or concern at its reconstitution by Christ. The smelly, dead body of Lazarus, therefore, offered one of the keys to challenge their opponents' use of 1 Cor 15.50 and rejection of the flesh. Describing the flesh as the "handiwork of God" ${ }^{86}$ rather than

\footnotetext{
${ }^{84}$ Tertullian, Marc. 3.10 (SC 399).

${ }^{85}$ Origen, Cels. 5.14 (SC 147).

${ }^{86}$ Irenaeus, Haer. 5.9.1. (SC 153).
} 
something 'worse than dung ${ }^{87}$ they used God's ability to resurrect and restore Lazarus in body and soul to ask why God would not do greater things in the resurrection to eternal life. Lazarus, therefore, becomes the model for the resurrection of the flesh and the linchpin for reclaiming and interpreting Paul's words. Paul's statements about flesh, blood, the kingdom of God, and the resurrection body force early Christians to look beyond the words of the Apostle in order to defend and preserve their arguments for the integrity and salvation of the flesh and an assurance of bodily resurrection. And for this, the decomposing, putrid, and risen body of Lazarus is absolutely essential.

${ }^{87}$ Origen, Cels. 5.14 (SC 147). 